\title{
The Effect of Perception of Justice Remuneration and Organizational Commitment Toward the Performance of Blu University in Inspectorate Region II
}

\section{Dewi Prastiwi}

Accounting, Universitas Negeri Surabaya, Indonesia

\section{Abstract}

The implementation of Public Service Agency (BLU) governance in University is a form of bureaucratic reform in the public sector to improve education services for the public. To encourage performance leading to sound business practices, a remuneration reward system is implemented at BLU. Remuneration is expected to be able to improve the public reward sector that is currently considered not to prioritize the element of justice. Justice is a middle ground for a transactional relationship to last. Everyone

Corresponding Author: Dewi Prastiwi

dewiprastiwi@unesa.ac.id

Received: 29 January 2019 Accepted: 27 February 2019 Published: 24 March 2019

Publishing services provided by Knowledge E

(c) Dewi Prastiwi. This article is distributed under the terms of the Creative Commons

Attribution License, which permits unrestricted use and redistribution provided that the original author and source are credited.

Selection and Peer-review under the responsibility of the 3rd ICEEBA Conference Committee. tries to reach the point of justice, so that the perception of fairness of remuneration greatly influences the behavior of members of the organization. This study aims to prove whether the perception of distributive justice and procedural remuneration can improve the performance of PT BLU through organizational commitment. The results showed that the perception of justice was not able to increase the commitment of BLU employees. Respondents in this study still perceive that the remuneration system that is currently being developed has not fulfilled the elements of both distributive and procedural justice so that the system needs to continue to be developed to reach the point of justice for all employees within BLU University.

Keywords: perception, distributive justice, procedural, remuneration, commitment, performance

\section{Introduction}

The implementation of BLU governance is a form of bureaucratic reform in the public sector to serve the needs of the community. Public Service Agency (BLU) according to PP No. 23 of 2005 is an agency within the Government that functions to provide services to the public in the form of the provision of non-profit oriented goods and/or services that are carried out based on the principles of efficiency and productivity. The purpose of BLU is to improve services to the public in order to promote public welfare and to educate the lives of the nation by providing flexibility in the financial management system based on economic principles and productivity, and the application of sound business 
practices. With budget flexibility, BLU is expected to be able to provide services quickly and optimally, as well as to encourage sound business practices.

BLU's Human Resources productivity and performance can be achieved if it is balanced with an increase in welfare, because on individual social behavior is based on profit and loss calculations. This is also argued by sociologists George Homans (1961), Richard Emerson (1962), and Peter Blau (1964) in Social Exchange Theory [16]. Social Exchange Theory presupposes that when an individual is happy with the rewards provided by the organization they will reciprocate by developing a positive attitude toward their organization such as a higher level of commitment [8]. This theory states that behavior with the environment has a reciprocal relationship. Because the environment generally consists of other people, we and other people are seen as having behaviors that influence each other and in that relationship there are elements of reward, cost and profit.

Remuneration is a reward system applied in BLU to encourage the performance of BLU employees. Remuneration is the provision of salary/honorarium/allowances/ incentives that are measured based on the level of responsibility, productivity and demands for professionalism. The purpose of remuneration is to encourage quality human resources $(\mathrm{HR})$, maintain productive human resources so that they do not move to the private sector and shape service-oriented behaviors and reduce acts of Corruption, Collusion and Nepostime.

There are two things that need to be considered by BLU in the implementation of remuneration, namely fair and proportional. Justice is a lasting middle way for a transactional relationship. Anyone wants to get fair treatment as a group member, because fair treatment shows recognition of their membership and their status in a community. If BLU employees feel that the remuneration system developed upholds justice and is performance based, it can increase satisfaction. Individuals who are satisfied with their work tend to be committed to the organization, so that employee loyalty appears to the organization, which increases the sense of dependency and responsibility in the organization [15].

Referring to pasal 65 ayat (1) Undang-undang Nomor 12 of 2012 concerning Higher Education states that:

The implementation of Higher Education autonomy can be given selectively based on the performance evaluation by the Minister to State Universities by implementing the Public Service Agency Financial Management Pattern or by establishing a legal entity State University to produce quality Higher Education. 
Based on this law, the College is given the opportunity to apply the financial management pattern of the Public Service Agency (BLU) or by establishing a Legal Entity State University. For Universities that have a Public Service Agency status, financial management flexibility can be realized by implementing remuneration. BLU University remuneration can be formulated internally by considering the amount of Non-Tax State Revenues.

The remuneration system in the University still raises pros and cons among the community and within the BLU employees themselves. In several surveys that have been conducted show that the remuneration system has disturbed the sense of justice in the community [13]. The achievement of bureaucratic performance in terms of productivity, service quality, responsiveness, responsibility and accountability is still considered low. In several studies, one of the respondents from BLU University employees stated that the remuneration received had not fulfilled the aspect of justice because it was not in accordance with the workload that had been carried out. The implementation of remuneration is not yet entirely based on performance and the remuneration is not yet a single salary (single payroll system). There has been no transparency on remuneration, there are still many unofficial honor/incentives received from non-salary posts, not yet reflected in the fair and proportional principles of the remuneration system.

Perception of justice has long been an explanatory variable in organizational research. Organizational justice describes the perceptions of individuals (or groups) of the fairness of the treatment received from an organization and their behavioral/behavioral reactions to these perceptions. There are two aspects of justice, namely distributive justice and procedural justice. Distributive justice and procedural justice are consistently correlated with work attitudes and work behavior of members of the organization [7]. For example, Folger and Konovsky (1989) report distributive justice has a stronger correlation with salary satisfaction compared to procedural fairness, whereas procedural justice has a stronger correlation with organizational commitment and supervisor/supervisor trust compared with distributive justice. In general, the findings in the existing justice literature show that distributive justice has a stronger correlation with personal outcomes (such as job satisfaction), while procedural justice has a stronger correlation with institutional evaluation and employee contributions/contributions (Lind and Tyler, 1988).

In connection with this research a number of previous studies noted that there was a significant relationship between the remuneration or compensation system and the performance in the form of service quality in the public sector [27]. However, [26] research shows that pay for performance has a negative effect on performance because it will result in a hidden cost of reward; [22] study states that incentive-oriented systems have 
a negative impact on performance. The purpose of this study was to explain the research gap by proving empirically the influence of fairness perceptions of individual remuneration on organizational commitment and organizational performance

\section{Literature of Review and Development of Hypotheses}

The issue of justice has become a concern for parties involved in a transaction. According to Adams, Shaw \& Costanzo in [3], Equity Theory assumes that people are motivated to maintain a balance in exchange relations and assess this balance by comparing their inputs and results with other inputs and results. A person's behavior is always encouraged to achieve justice. Justice is a middle ground from all the demands of the individualistic ratio so that interactions and transactions can be perpetuated.

Organizational Justice Theory assumes that people will concentrate on two types of justice, namely distributive justice and procedural justice [3]. Distributive justice relates to the fairness of the distribution of results between themselves and other relevant ones. Procedural justice refers to the fairness of the process by which results are determined independently based on what the actual results are. Individuals generally consider the process as fair when they have a voice (the ability to express their opinions) and/or people (the ability to influence the outcome of a decision).

For Homans, the basic principle of social exchange is the 'distributive justice' rule which says that a reward must be proportional to investment. A well-known proposition regarding this principle reads:

someone in an exchange relationship with another person would expect the reward received by each party to be proportional to the sacrifice he has made - the higher the sacrifice, the higher the reward - and the profit received by each party must be proportional to his investment - the higher the investment, the higher the profit.

An individual always interacts with the environment. He sees, hears, and feels something. From what he received, he would interpret, conclude, assess and give attitude to what he felt. This process is called perception. According to Moskowitz and Orgel (1969) perception is a process that is integrated from an individual to the stimulus he receives. With individual perceptions can be realized, can understand about the state of the environment around him, and also about the individual's own condition in [4]. While [18] provides a definition of perception as a process of receiving, selecting, organizing, interpreting, testing, and reacting to sensory or data stimuli. Perception is formed 
because the stimulus received by the individual both from the outside of the individual and from within the individual concerned.

One reason for the low quality of public services is because of the perception of injustice the reward system is implemented; which has an impact on employee motivation [14]. Payroll systems that are not based on performance lead to being motivated to show their best performance. Remuneration is a payroll system developed based on the principle of fairness, which is formulated based on performance. One of the roles of remuneration is to create balance and justice between 'input' and 'output' [2]. The better the employee's performance, the greater the remuneration obtained. This system is expected to increase employee satisfaction so as to motivate employees to be more committed to the organization. Based on this, a hypothesis is formulated:

H1: Perceptions of distributive remuneration justice affect organizational commitment.

Remuneration is a reward given by BLU as compensation for the performance achieved. The determination of the BLU remuneration calculation formula by the government is left to the policy of each BLU which is followed up by being determined by the remuneration team and the relevant officials. Based on the self-interest model [23]; Lind and Tyler 1988), everyone wants to be involved in the process because they focus on the outcome they get. Perception of justice increases when individuals are given the opportunity to participate because individuals believe that their input plays a role in achieving the desired results; the opportunity to provide input is a form of recognition of the existence of employees in an organization.

Two popular aspects of justice are distributive and procedural. Distributive justice refers to the fairness of an employee's actual results received (Gilliland 1993; Cohen 1987; Adams 1965; Homans 1961), whereas procedural justice relates to the fairness of procedures used to determine distributive outcomes of people. Fairness perceptions contribute to the level of individual commitment, [5], found a significant positive relationship between procedural fairness and task commitment in the experimental group sample, while [11] showed that team members showed greater commitment to strategic decisions when they saw the process being carried out fairly., Lind et al. (1990) found that individuals more accepting the goals set under fair procedural experimental conditions. The application of procedural justice theory with the issue of commitment shows a positive relationship. In particular, when individuals perceive that decisions are based on a fair process, they are more likely to commit because they believe the results of these decisions are in line with their own interests (i.e., instrumental perspectives) or because 
their compliance confirms their group membership (i.e., relational perspectives) Based on this, the hypothesis is formulated:

$\mathrm{H}$ 2: Perception of procedural justice in remuneration influences organizational commitment

To create a professional work climate, commitment is needed both to the company's commitment to employees, and between employees to the company. Individuals who are satisfied with their work tend to be committed so that loyalty appears and has a sense of dependence and responsibility on the organization. With the commitment that is owned, the individual will try to provide all the power he has in order to realize the goals of the organization.

Organizational commitment is a view of an individual's value orientation toward an organization that shows individuals are very concerned about and prioritize their work and organization [24]. So that individuals will try to provide all the strength they have in order to realize organizational goals. Organizational commitment is defined as "The degree to which an employee identifies with a particular organization and its goals, and wishes to maintain membership in the organization" [19]. Furthermore, [17] defines organizational commitment as the relative strength of individuals toward an organization and its involvement in the organization certain, which are characterized by three psychological factors: (1) a strong desire to remain a member of a particular organization, (2) a desire to do everything possible for the organization and (3) a definite belief and acceptance of the values and goals of the organization.

Proposed three forms of organizational commitment, namely: First, Affective commitment, namely emotional attachment, identification and involvement in an organization. In this case the individual lives in an organization because of his own desires. Second, continuance commitment, which is individual commitment based on consideration of what must be sacrificed if they leave the organization. In this case the individual decides to stay in an organization because he considers it as a fulfillment of needs. Third, Normative commitment, namely the individual's beliefs about responsibility for the organization. Individuals remain in an organization because they feel obliged to be loyal to the organization [1].

Organizational performance is the level of organizational achievement in a certain period. With the development of technology and competition, performance measurement based solely on financial measurement, is no longer sufficient. The company is also required to measure its non-financial performance, such as the level of customer satisfaction, product innovation, company development and employee development 
called balance scorecard performance measurement developed by Robert S Kaplan and David P. Norton Kaplan in 1990 [10]. Indicators of Higher Education performance are Accreditation BAN PT. According to R. Eko Indrajit and R. Djokopranoto explained that balanced scorecard can be applied to universities based on 4 perspectives [9], namely: customer perspective: institutional customers, financial perspective: college financing profiles, internal process perspectives: assessment and measurement of lecturer performance, growth perspective: understanding and measuring lecturer productivity. Based on this, a hypothesis is formulated:

H3: Organizational Commitment has a significant effect on the performance of University BLU

\section{Research Methodology}

\subsection{Research design}

This research is based on explanatory research, which is research that aims to test and explain the relationship, differences and influence of one variable with another variable, which is done using the survey method. Survey method is a system to collect information from or about people to describe, compare, or explain their knowledge, attitudes, and behavior [21]. The questionnaire consists of two parts, namely the first part contains a number of questions of respondents' data; the second part contains a number of questions related to the opinions of respondents to the variables studied

\subsection{Population and research sample}

The research population is educators and education personnel in the BLU Higher Education environment which is used as the object of research. Based on the data, the number of BLU PTN employees who were sampled was 1625 people, consisting of 899 PNS Lecturers; 36 Permanent Non-Civil Servant Lecturers; 438 PNS educators; 162 University Non-permanent Workers; 54 Contract Workers; and 36 Faculty Non-permanent Workers. Referring to the opinion of Roscoe in Sugiyono, the number of sample members is at least 10 times the number of variables studied. In this study there are 2 independent variables; 3 mediating variables and 1 dependent variable, so that the minimum number of samples in this study were 60 samples with convenience sampling design. 


\subsection{Variable operational definition}

This study consisted of independent variables, mediation and dependent variables. The variables of this study were measured using a Likert scale, where respondents stated the level of agreement or disagreement regarding various statements regarding behavior, objects, people, or events with answers and scales:

1. Strongly disagree

2. Disagree

3. Neutral

4. Agree

5. Strongly Agree

The operational definition of each variable used in this study is as follows:

\subsubsection{Independent variables}

1. Perceptions of distributive justice are employee perceptions of the balance of sacrifices that have been given in return for remuneration received. Distributive Justice is measured by using employee responses to five indicator items adapted from Magner and Johnson (1995).

2. The perception of procedural justice is the employee's perception of the opportunity to participate or convey input to achieve the desired remuneration results. Procedural justice is measured by using responses from eight statements of procedural justice. Six items were adapted from Skla Magner and Johnson (1995), which relate to five of the six rules [12] to determine the fairness of allocation procedures (consistency between people and time, accuracy, correctability, ethicality, and suppression bias). And two items developed referring to [12] rules and procedural justice aspects [7]. Overall, perceptions of distributive and procedural justice are measured by questions developed from the following indicators:

\subsubsection{Mediation variables}

Perception of Organizational commitment. Referring to [17], Organizational commitment is defined as the relative strength of individuals toward an organization and its involvement in a particular organization, which is characterized by three psychological factors: 
TABLE 1: Indicator of measurement of perception of justice.

\begin{tabular}{|c|c|c|}
\hline No. & Variables/Constructions & Indicator \\
\hline 1 & Distributive Justice & $\begin{array}{l}\text { The remuneration system developed has fulfilled the } \\
\text { feasibility aspect; } \\
\text { The remuneration system developed has been adequate } \\
\text { and reflects needs; } \\
\text { Remuneration system developed as expected; } \\
\text { The remuneration system developed has been distributed } \\
\text { fairly; } \\
\text { Decision-makers pay attention and to the remuneration } \\
\text { system developed }\end{array}$ \\
\hline 2 & Procedural Justice & $\begin{array}{l}\text { The remuneration system developed is applied consistently } \\
\text { among people; } \\
\text { The remuneration system developed is applied consistently } \\
\text { throughout time; } \\
\text { Remuneration is determined based on valid information; } \\
\text { The remuneration system gives employees the opportunity } \\
\text { to appeal; } \\
\text { The remuneration system developed meets the standards } \\
\text { of the applicable rules; } \\
\text { The remuneration system developed is impartial; } \\
\text { Remuneration is developed to represent the interests of all } \\
\text { parties; } \\
\text { Decision-makers provide complete information regarding } \\
\text { the formulation of remuneration policies }\end{array}$ \\
\hline
\end{tabular}

(1) a strong desire to remain a member of a particular organization, (2) a desire to do everything in their power for the sake of the organization and (3) Confidence and acceptance of organizational values and goals. Organizational commitment is measured by using responses from several statements that refer to [1] about three forms of organizational commitment, namely: Affective Commitments, Continuity Commitments, Normative Commitments. Overall commitment is measured by questions developed from the following indicators:

TABLE 2: Indicator of commitment measurement.

\begin{tabular}{|c|c|c|}
\hline No. & Variables/Constructions & Indicator \\
\hline 1 & Affective Commitment & $\begin{array}{l}\text { There is an emotional attachment between employees } \\
\text { and the organization } \\
\text { The desire of employees to be involved in } \\
\text { organizational activities }\end{array}$ \\
\hline 2 & Continuous Commitment & $\begin{array}{l}\text { The desire of employees to survive in the organization } \\
\text { Consideration of loss when leaving the organization }\end{array}$ \\
\hline 3 & Normative Commitment & $\begin{array}{l}\text { Employee confidence to be responsible for the } \\
\text { organization } \\
\text { Employee loyalty to the organization. }\end{array}$ \\
\hline
\end{tabular}




\subsubsection{Dependent variables}

BLU University Performance. Performance is defined as a measure of employee contributions in realizing the goals of an agency through the completion of the tasks for which it is responsible. The performance in this study was measured by balance scorecard [10]. This approach is based on 4 perspectives, namely finance, customers, internal business processes and learning and growth. BLU College Performance is measured by questions developed from the following indicators:

TABLE 3: Indicator of organizational performance measurement.

\begin{tabular}{|c|c|c|}
\hline No. & Variables/Constructions & Indicator \\
\hline 1 & Performance: Financial perspective & $\begin{array}{l}\text { An increase in revenue } \\
\text { There is a decrease in costs and increased } \\
\text { productivity } \\
\text { There is an optimization of asset utilization }\end{array}$ \\
\hline 2 & Performance: Customer Perspective & $\begin{array}{l}\text { There is an increase in the number of } \\
\text { applicants every year } \\
\text { There is an increase in the number of } \\
\text { students every year } \\
\text { The number of students is higher than other } \\
\text { universities for the same class } \\
\text { Students are satisfied with the services of PT. } \\
\text { Stakeholders are satisfied with alumni } \\
\text { performance. }\end{array}$ \\
\hline 3 & $\begin{array}{l}\text { Performance: Internal Business Process } \\
\text { Perspective }\end{array}$ & $\begin{array}{l}\text { There are innovations both externally and } \\
\text { internally } \\
\text { The Teaching and Learning Process has been } \\
\text { carried out in accordance with the BAN } \\
\text { standards of PT } \\
\text { There is an organizational responsibility for } \\
\text { the alumni's opportunity to get a job }\end{array}$ \\
\hline 4 & $\begin{array}{l}\text { Performance: Growth and Learning } \\
\text { perspective }\end{array}$ & $\begin{array}{l}\text { All employees have worked with full } \\
\text { competence } \\
\text { The development of a system to support the } \\
\text { implementation of organizational activities } \\
\text { There is a commitment to encourage and } \\
\text { facilitate education and education personnel } \\
\text { to increase their capacity }\end{array}$ \\
\hline
\end{tabular}

\subsection{Analysis method}

Testing the hypothesis in this study using the Smart Partial Least Square (SmartPLS) software version 3.0. PLS analysis consists of two sub models, namely the measurement model or called the outer model and structural model or called the inner model. The measurement model shows how the manifest or observed variable presents/forms a 
latent variable to be measured. While the structural model shows the strength of estimation between latent or construct variables. The purpose of the model is measured to test the reliability and validity of items or indicators that form the construct. Whereas for the structural model is intended to determine the effect between variables or constructs in the model. The following path diagram illustrates the relationship between latent variables (constructs) both exogenous and endogenous:

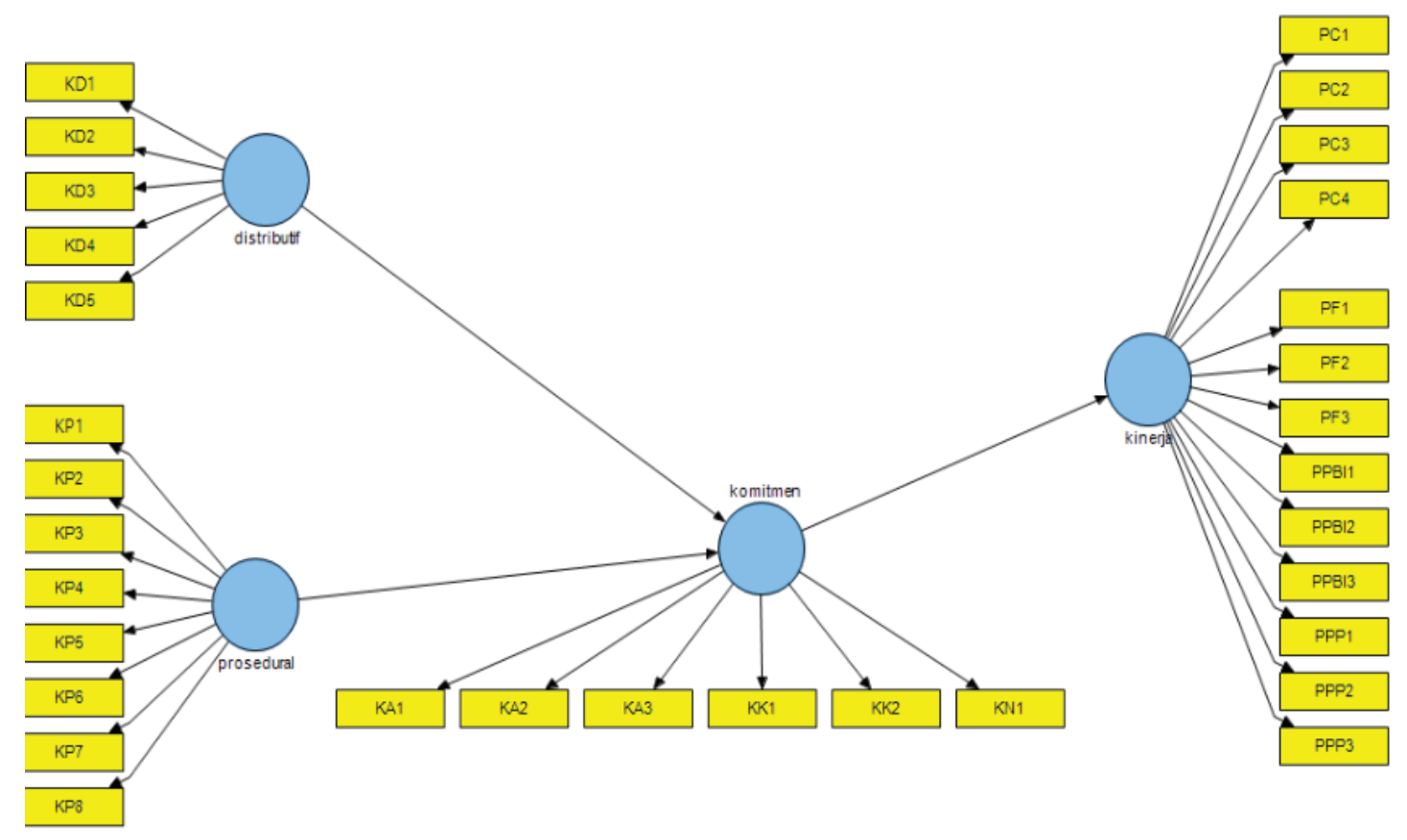

Figure 1: Path diagram.

\section{Analysis of Research Results}

Researchers deployed a number of employees in PT who were used as sampling. From the questionnaires distributed, the returned questionnaires were 187 and the ones that could be processed were 91 questionnaires. Questionnaires that cannot be processed because they are not filled in completely so they must be deleted. The number of sample uses is 91 respondents which have fulfilled the requirements to get maximum likelihood, which is a sample with a size of 10 times the number of variables. In this study researchers used 6 variables, consisting of 2 independent variables; 3 mediating variables and 1 dependent variable. 
BLU university which was used as the object of research was BLU universities in Eastern Indonesia which gained BLU status starting in 2009, and began implementing the remuneration system starting in 2015. BLU university consists of 7 faculties and 1 postgraduate program, with a total number of 1625 employees consisting of 899 Government Employees Lecturers; 36 Permanent Non-Civil Servant Lecturers; 438 Government Employees educators; 162 University Non-permanent Workers; 54 Contract Workers; and 36 Faculty Non-permanent Workers. Demographically, the respondents of this study consisted of $57 \%$ of men and $43 \%$ of women. Respondent age is less than 30 years (16\%); in the range of $30-40$ years ( $42 \%$ ) and more than 40 years by $42 \%$. For class positions, $2 \%$ of respondents are group I; $11 \%$ of class II respondents; $65 \%$ of class III respondents; $12 \%$ of class IV respondents. In terms of education, respondents with high school education were $8 \%$; D3 is $5 \%$; scholars by $30 \%$; postgraduate as much as $45 \%$; doctoral education by $11 \%$. And $27 \%$ of respondents said that they had income outside their income as civil servants and $73 \%$ said they did not have other income.

\subsection{Model analysis}

\subsubsection{Outer model analysis}

Measurement model analysis or outer model is done to assess the reliability and validity of latent construct forming indicators. Validity testing is intended to test whether items/indicators that present a valid latent construct or not. Validity test in this study is divided into two, namely: convergent validity and discriminant validity. Convergent validity aims to examine the correlation between items/indicators to measure constructs [6]. The results of convergent validity testing are seen based on loading factors, with criteria $>0.70$ or AVE value $>0.50$.

The results of the discriminant validity test are seen based on the comparison of AVE with the correlation between constructs, namely if $\mathrm{AVE}>$ correlation between constructs. Discriminant validity aims to test items/indicators from two constructs that should not have a high correlation. The results of testing the validity of stage 1 AVE values of all indicators > 0.5, except for commitment indicators (KN2) and performance (PC5). To improve the results of the validity test, the two indicators are issued. The results of testing phase 2 show that all indicators are valid as indicated by the AVE value $>0.5$ as shown in Table 4.

Reliability testing is intended to test whether the items/indicators of the instrument can be used to measure more than twice with accurate results. Reliability test results 
are seen based on the Cronbach's Alpha value, that is, with Cronbach's Alpha $>0.6$ and composite reliability value with criteria $>0.6$. Based on the results of the reliability test all indicators have a value of Cronbach's Alpha $>0.6$, which means that all indicators are reliable. The results of the validity and reliability tests are shown in the following table:

TABLE 4: Validity test \& Reliability test results.

\begin{tabular}{|l|c|c|c|c|c|c|}
\hline & AVE & $\begin{array}{c}\text { Composite } \\
\text { Reliability }\end{array}$ & R Square & $\begin{array}{c}\text { Cronbach's } \\
\text { Alpha }\end{array}$ & Communality & Redundancy \\
\hline Distributive & 0.664592 & 0.908230 & & 0.881822 & 0.664592 & \\
\hline Performance & 0.634611 & 0.838792 & 0.254450 & 0.714921 & 0.634611 & 0.158544 \\
\hline Commitment & 0.642683 & 0.899857 & 0.070352 & 0.862394 & 0.642683 & -0.025036 \\
\hline Procedural & 0.609602 & 0.903516 & & 0.872464 & 0.609602 & \\
\hline
\end{tabular}

\subsubsection{Inner model analysis}

Inner model analysis aims to predict the relationship between latent variables by seeing how much variance can be explained and to find out the significance of $P$-value. In assessing the inner model with PLS, by looking at the values of R-Square and Q Square. $\mathrm{R}$ Square shows the extent to which a construct is able to explain the model. Q Square shows predictive relevance value. Based on Table 4 the average value of $R$ Square is below 0.6 , which means that the model is a poor predictor in explaining variance.

\subsection{Hypothesis test results}

TABLE 5: Hypothesis test results.

\begin{tabular}{|c|c|c|c|c|c|}
\hline & $\begin{array}{c}\text { Original } \\
\text { Sample (O) }\end{array}$ & $\begin{array}{c}\text { Sample } \\
\text { Mean (M) }\end{array}$ & $\begin{array}{c}\text { Standard } \\
\text { Deviation } \\
\text { (STDEV) }\end{array}$ & $\begin{array}{l}\text { Standard } \\
\text { Error } \\
\text { (STERR) }\end{array}$ & $\begin{array}{l}\text { T-Statistics } \\
\text { (|O/STERRI) }\end{array}$ \\
\hline Distributive $\rightarrow$ Performance & -0.048386 & -0.027182 & 0.091620 & 0.091620 & 0.528120 \\
\hline $\begin{array}{l}\text { Distributive } \rightarrow \\
\text { Commitment }\end{array}$ & -0.095922 & -0.056777 & 0.181904 & 0.181904 & 0.527324 \\
\hline $\begin{array}{l}\text { Commitment } \rightarrow \\
\text { Performance }\end{array}$ & 0.504431 & 0.512344 & 0.110486 & 0.110486 & 4.565562 \\
\hline Procedural $\rightarrow$ Performance & 0.167541 & 0.168864 & 0.102208 & 0.102208 & 1.639221 \\
\hline Procedural $\rightarrow$ Commitment & 0.332139 & 0.325871 & 0.179699 & 0.179699 & 1.848307 \\
\hline
\end{tabular}

To check whether the hypothesis is accepted or rejected, it can be seen from the statistical $t$-value. If the statistic $t$-value $>1.96$, the independent variable has a significant effect of $5 \%$ on the dependent variable or the hypothesis is accepted. Based on Table 
5 above, only the commitment hypothesis influences the organizational performance received.

\section{Discussion and Conclusion}

According to Government Regulation No. 69 of 2010 remuneration is the reward or remuneration provided by the company to the workforce as a result of the achievements given in order to achieve company performance. Remuneration is expected to create fair distribution of income and is expected to motivate employees to perform better. Remuneration consists of three main components, namely: 1) Pay for position, remuneration is given on the basis of appreciation for his work. The amount is fixed and is paid periodically (every month); 2) Pay for performance, remuneration is given on the basis of performance achievement within the company. The amount is not fixed in accordance with performance achievements; 3) pay for people, remuneration based on individual conditions. Usually given in the form of insurance premiums, severance pay, pensions, etc. The remuneration structure consists of seven components, namely: Salary, living expenses; performance allowances; holiday allowance; compensation allowance; health contributions and master's day allowance contributions.

Remuneration policies can be developed internally by each work unit. There are 2 types of grading performance/remuneration benefits that have been used by Ministries/Institutions in Indonesia, namely the Hays method and the Factor Evaluation System (FES) method. But what is commonly used is the FES method. The Factor Evaluation System is a common method used in determining levels within an organization. This level is usually given a numeric symbol. Each level indicates the level of difficulty and responsibility of a position which also shows the level of wages and the level of qualification required in that position. FES is used to determine the class of a position that has not been classified in the organization. Use of the FES Method in Evaluation Structural and functional positions have different evaluation factor information. Each of the position evaluation factors above is given a score (score) that has been determined and translated again in a range that has a different value.

The results showed that the perception of distributive justice and procedural remuneration had no effect on organizational commitment. This is because most respondents perceive that the remuneration system that is currently being developed does not fulfill the element of justice. This is due to:

1. If the Remuneration System refers to the FES method, it will apply the grading system to each class of office, so that if someone occupies a certain position, 
it is certain that the pay for position is high and permanent. Not all employees understand that the position/position is not only related to the task, but also related to responsibility. Most employees still think that even though employees who are of lower class but who are active performers will get lower remuneration, or vice versa even though the class is the same but the activity is different, the remuneration received can be the same.

2. Proof of performance is measured by a letter of assignment not yet on real performance results. The phenomenon of assignment letters with various nomenclature is very easy to make. Employees have the tupoksi that should have been paid from the salary, while the remuneration is paid for non-duty activities. While the assignment letter was unable to detect this.

3. There is a remuneration gap between lecturers and educators.

4. The remuneration system applies a portal system. If the employee's performance meets certain portal limits, then additional performance does not affect remuneration.

5. The remuneration system is not yet a single salary system, where there are still some activities that are paid in the form of an honorarium

Perception of procedural justice is a perception of the opportunity to participate/ deliver input to achieve the desired remuneration results. The opportunity to voice opinions in the policy formulation process is a form of recognition of the existence of members of the organization, which ultimately creates an emotional bond to remain in the organization. But this bond will only last when procedural justice is fulfilled. The results also showed that the perception of procedural justice had no effect on commitment because respondents felt that they were not involved in the process of formulating remuneration policies or inputs and complaints regarding the remuneration they received had not been fully acted upon.

The results of the third study indicate that commitment influences organizational performance. Commitments in this study are divided into 3, namely: affective commitment, normative commitment, and continuance commitment. Affective commitment is a commitment based on one's emotional sense with the organization. This commitment is the highest level of commitment. If the employee has committed an affective then the reward is no longer a consideration to survive in an organization. Normative commitment refers to the individual's feeling of the obligation to remain in the organization. Individuals with a high level of normative commitment to survive in an organization are a must. Continuous 
commitment refers to what comes from the perceived opportunity costs of leaving the organization in case they are unable to find similar opportunities elsewhere. Continuity commitment is the lowest form of commitment, because if there are better opportunities, employees with this commitment are not reluctant to leave the organization. All types of commitment encourage employees to do everything that is best for the progress of the organization whatever the underlying reason, whether it is due to emotional connection, an obligation or because there is no other choice.

Designing a remuneration program is a complex process. The policy makers must really understand the business processes of PT BLU and understand the activities in the PT that are truly able to contribute to the performance of PT BLU. Performance measurement and proof of performance are also crucial in the implementation of the remuneration system. The system must be able to define the performance measures appropriately and the calculation process must also attach valid evidence. To ensure a level of transparency and accountability, the remuneration calculation process must also be supported by data from many sources and manage the data to be structured so that everyone can understand and use it. The structure must meet the appropriate needs and be adjusted to the company's ability to pay. All of this cannot be achieved through indiscriminate methods. This requires the development of an appropriate system, because people may do a lot of wrong managerial actions, but when dealing with payments they are very careful.

\section{References}

[1] Allen, N. J. and Meyer, J. P. (1990). The measurement and antecendents of affective, continuance and normative commitment to the organization. Journal of Occupational Psychology, vol. 63, no. 1, pp. 1-18.

[2] Angliawati, R. Y. (2016). Peran remunerasi terhadap kualitas pelayanan publik区: Theoretical review. Ecodemica, vol. IV, no. 2, pp. 203-213.

[3] Birnberg, J. G., Luft, J., and Shields, M. D. (2006). Psychology theory in management accounting research. Handbooks of Management Accounting Research, vol. 1, pp. 113-135.

[4] Davidoff, L. L. (1981). Introduction to Psychology (second edition). Tokyo: McGraw-Hill International Book Company.

[5] Earley, P. C. and Lind, E. A. (1987). Procedural justice and participation in task selection: The role of control in mediating justice judgments. Journal of Personality and Social Psychology, vol. 56, no. 6, pp. 1148-1160. 
[6] Ghozali, I. (2014). Partial Least Squares: Konsep, Metode dan Aplikasi (second edition). Semarang: Universitas Diponegoro Semarang.

[7] Greenberg, P., Greenberg, R. H., and Nouri, H. (1994). Participative budgeting: A metaanalytic examination of methodological moderators. Journal of Accounting Literature, vol. 13, pp. 117-141.

[8] Haar, J. M. and Spell, C. S. (2004). Programme knowledge and value of work-family practices and organizational commitment. International Journal of Human Resource Management, vol. 15, no. 6, pp. 1040-1055.

[9] Hamzah, S. and Mudjihatono, P. (2010). Sistem Pendukung Keputusan Penilaian Kinerja Dosen Dengan Metode Balanced Scorecard (Studi Kasus: Universitas Respati Yogyakarta). Seminar Nasional Informatika 2010 (SemnasIF), pp. 82-90.

[10] Kaplan, R. S. and Norton, D. P. (1996). Balanced Scorecard. Jakarta: Erlangga.

[11] Korsgaard, M. A., Schweiger, D. M., and Sapienza, H. J. (1995). Building commitment, attachment, and trust in strategic decision-making teams: The role of procedural justice. Academy of Management Journal, vol. 38, no. 1, pp. 60-84.

[12] Leventhal, G. S. (1980). What should be done with equity theory? in K. J. Gergen, M. S. Greenberg, and R. H. Willis (eds.) Social Exchange: Advances in Theory and Research, pp. 27-55. New York, NY: Plenum Press.

[13] Martini, R. (2011). Remunerasi dan Rasa Keadilan Masyarakat, Majalah Pengembangan Ilmu Sosial.

[14] Mukhti, I. and Fachruddin, R. (2016). Pengaruh Remunerasi Terhadap Motivasi Dalam Pelayanan Publik. Jurnal IImiah Mahasiswa Ekonomi Akuntansi (JIMEKA), vol. 1, no. 1, pp. 306-317.

[15] Murty, W. A. and Hudiwinarsih, G. (2012). Pengaruh Kompensasi, Motivasi Dan Komitmen Organisasional Terhadap Kinerja Karyawan Bagian Akuntansi (Studi Kasus Pada Perusahaan Manufaktur Di Surabaya). The Indonesian Accounting Review, vol. 2, no. 2, pp. 215-228.

[16] Mustafa, H. (2011). Perilaku Manusia Dalam Perspektif Psikologi Sosial. Junal Administrasi Bisnis FISIP: Unpar, vol. 7, no. 2, pp. 143-156.

[17] Porter, L. W. and Steers, R. M. (1973). Organizational, work, and personal factors in employee turn over and absenteeism. Psychological Bulletin, vol. 80, no. 2, pp. 151176.

[18] Pareek, U. (1996). Perilaku Organisasi. Jakarta: Pustaka Binaman Pressindo.

[19] Robbins, P. S. (2003). Perilaku Organisasi: Konsep, Kontroversi, dan Aplikasi. Alih Bahasa Handayana Pujaatmika, Edisi Bahasa Indonesia. Jakarta: Prenhalindo. 
[20] Rivai, H. A. (2005). Pengaruh Kompensasi, komitmen Organisasional, dan Kompetensi terhadap Kinerja Individual. Kajian Bisnis, vol. 3, p. 272.

[21] Sekaran, U. and Bougie, R. (2017). Metode Penelitian untuk Bisnis (sixth edition). Jakarta: PT Salemba Empat.

[22] Speklé, R. F. and Verbeeten, F. H. M. (2014). The use of performance measurement systems in the public sector: Effects on performance. Management Accounting Research, vol. 25, no. 2, pp. 131-146.

[23] Tyler, T. R. (1989). The psychology of procedural justice: A test of the group-value model. Journal of Personality and Social Psychology, vol. 57, no. 5, pp. 830-838.

[24] Tobing, K. L. S. D. (2009). Pengaruh Komitmen Organisasional dan Kepuasan Kerja terhadap Kinerja Karyawan PT. Perkebunan Nusantara III di Sumatera Utara. Jurnal Manajemen dan Kewirausahaan, vol. 11, no. 1, pp. 31-37.

[25] Undang-undang Nomor 12 Tahun 2012 tentang Pendidikan Tinggi

[26] Weibel, A., Rost, K., and Osterloh, M. (2010). Pay for performance in the public sector - Benefits and (Hidden) costs. Journal of Public Administration Research and Theory, vol. 20 , no. 2 , pp. 387-412.

[27] Werther, W. B. and Davis, K. (1996). Human Resources and Personel Management. Boston: McGraw Hill, Inc.

[28] Zalbianis and Sanusi, R. (2006). Hubungan Besar Sisa Gaji yang Dibawa Pulang dan Komitmen Organisasi Dengan Ketidakhadiran Karyawan di Dinas Kesehatan Propinsi Jambi (Working Paper Series, No. 13 November), KMPK Universitas Gajah Mada, Yogyakarta. 